\title{
AKUNTABILITAS PRAKTIK PENGELOLAAN KEUANGAN DESA GAMTALA, HALMAHERA BARAT PROVINSI MALUKU UTARA
}

\author{
Zainuddin*1, Resmiyati Ansar ${ }^{2}$ \\ 1,2Program Studi Akuntansi, Fakultas Ekonomi dan Bisnis, Universitas Khairun, Indonesia \\ Jalan Pertamina Kampus II Gambesi Kota Ternate Selatan \\ *Email Correspondence: jhayunkhair@gmail.com
}

\begin{abstract}
Desa Gamtala is a social organization which has traditional characteristics, so that the accountability of its financial management process is not always supported by proper system and procedure. Although this system was carried out in simple way, this could be used to manage the asset of Desa Gamtala properly. To understand the phenomenon of the financial management in Desa Gamtala, this research was aimed to find out: 1) the participants involved in the financial management process in Desa Gamtala, 2) how the financial management process in Desa Gamtala was carried out, 3) how the participants involved understand and interpret the accountability of the financial management process. This research was conducted by using qualitative method which emphasizes on the description of every perception and habits of the human. The data analysis was conducted in three steps, such as: 1) Data Reduction, 2) Data Display, and 3) Verification. The result of this research shows that: 1) The process of financial management and its accountability in Desa Gamtala was involve all people in Desa Gamtala, 2) The accountability of the financial management is carried out consistently 3) Due to the social capital, especially belief, the participants of Desa Gamtala realize that accounting is an instrument of accountability and transparency in financial management in Desa Gamtala.
\end{abstract}

Keywords: Accountability, Social Capital, Financial Management Process

\begin{abstract}
Abstrak
Desa Gamtala merupakan organisasi sosial yang bersifat tradisional sehingga pertanggungjawaban pengelolaan keuangannya seringkali belum ditunjang dengan sistem dan prosedur yang memadai. Meskipun dilakukan dengan sederhana, namun sistem ini dapat dimanfaatkan untuk mengelola aset Desa Gamtala secara baik. Untuk memahami fenomana pengelolaan keuangan pada Desa Gamtala, penelitian ini bertujuan untuk mengetahui: 1) siapa saja pihak-pihak yang terlibat dalam proses pengelolaan keuangan di Desa Gamtala; 2) bagaimana proses pengelolaan keuangan di Desa Gamtala; dan 3) bagaimana pihak-pihak yang terlibat memahami dan memaknai akuntabilitas proses pengelolaan keuangan. Penelitian ini dilakukan dengan menggunakan metode kualitatif yang menekankan pada deskripsi setiap persepsi dan perilaku manusia. Analisis data dilakukan melalui tiga tahapan, antara lain; 1) Reduksi Data, 2) Penyajian Data, dan 3) Menarik Kesimpulan. Hasil penelitian ini menunjukkan bahwa; 1) Proses pengelolaan dan pertanggungjawaban keuangan di Desa Gamtala telah melibatkan seluruh pihak yang berkepentingan di Desa Gamtala; 2) Akuntabilitas pengelolaan keuangan berlangsung secara konsisten dalam dua tahun terakhir; 3) Dengan adanya modal sosial khususnya kepercayaan, Pengurus Desa Gamtala menyadari bahwa akuntansi merupakan instrumen akuntabilitas dan transparansi dalam pengelolaan keuangan di Desa Gamtala.
\end{abstract}

Kata Kunci: Akuntabilitas, Modal Sosial, Proses Pengelolaan Keuangan.

\section{PENDAHULUAN}

Salah satu aspek penting yang mampu mewujudkan Good Governance dan paling sering menjadi pembahasan publik adalah akuntabilitas. Akuntabilitas adalah kewajiban untuk memberikan pertanggungjawaban atau menjawab dan menerangkan kinerja serta tindakan seseorang/pimpinan suatu unit organisasi kepada pihak yang memiliki hak atau yang berwenang meminta 
pertanggungjawaban (Lembaga Administrasi Negara dan Badan Pengawasan Keuangan dan Pembangunan RI, 2000: 12). Akuntabilitas akan semakin membaik jika didukung oleh suatu sistem akuntansi yang menghasilkan informasi yang akurat, handal, tepat waktu, serta dapat dipertanggungjawabkan. Sejalan dengan hal tersebut, akuntabilitas publik merupakan suatu kewajiban bagi agen (sebagai pemegang amanah) untuk mempertanggungjawabkan, menyajikan, melaporkan serta mengungkapkan segala macam aktivitas kepada prinsipal (sebagai pemberi amanah), dimana prinsipal tentunya memiliki hak dan kewenangan untuk meminta pertanggungjawaban tersebut (Mardiasmo, 2002: 20).

Dalam hubungan antara agen dan prinsipal (agency theory), kemungkinan akan timbul suatu masalah apabila terdapat informasi asimetri yang menyebabkan agen melakukan tindakan yang menyimpang, seperti pemanipulasian data, sehingga laporan keuangan terlihat lebih bagus dan memenuhi harapan prinsipal meskipun tidak menggambarkan kondisi perusahaan yang seutuhnya. Berdasarkan hal tersebut akuntansi memiliki peranan yang sangat penting khusunya sebagai alat pertanggungjawaban (akuntabilitas) dalam hubungan antara prinsipal selaku pemberi tugas dan kekuasaan kepada agen untuk melakukan pekerjaan yang berkaitan dengan kepentingan prinsipal. Sementara itu, Simanjuntak (2011: 9) menyebutkan bahwa akuntanbilitas public terdiri Akuntabilitas Vertikal (akuntabilitas kepada otoritas yang lebih tinggi) dan Akuntabilitas Horizontal (akuntabilitas pada masyarakat umum dan lembaga lainnya yang setara). Sedangkan menurut Ellwood dalam Mardiasmo (2002: 22), akuntabilitas publik dapat dibagi menjadi 4 dimensi, yaitu: 1) Akuntabilitas Kejujuran dan Akuntabilitas Hukum (Accountability for Probity and Legality). 2) Akuntabilitas Proses (Process Accountability). 3) Akuntabilitas Program (Program Accountability). 4) Akuntabilitas Kebijakan (Policy Accountability).

Provinsi Maluku Utara sebagai salah satu provinsi yang ada di Indonesia memiliki keunikan tersendiri dalam sistem pemerintahannya. Provinsi Maluku Utara mengenal keberadaan desa Gamtala (Desa Adat dan Wisata). Desa Gamtala merupakan suatu kesatuan yang memiliki ikatan tradisi dan budaya yang sangat kuat dalam suatu kesatuan wilayah tertentu, memiliki pemimpin, serta memiliki kekayaan dan bersifat tradisional, orisinil serta spesifik. Selama ini pengelolaan keuangan desa Gamtala di Jailolo dapat dikatakan sederhana. Petanggungjawaban yang dibuat dalam bentuk laporan keuangan sampai saat ini belum ditunjang dengan sistem dan prosedur yang memadai, hal ini dikarenakan tidak adanya peraturan resmi yang dibuat baik dari pemerintah pusat maupun pemerintah daerah yang secara khusus mengatur mengenai pembuatan laporan keuangan desa Gamtala sebagai wujud akuntabilitas dalam pengelolaan keuangan di desa Gamtala. 
Akuntabilitas Praktik Pengelolaan Keuangan Desa..

Adanya laporan keuangan yang handal dari desa Gamtala sangat diharapkan sebagai wujud pertanggungjawaban kepada masyarakat desa Gamtala itu sendiri, sehingga persepsi maupun hal negatif terkait dengan pengelolan keuangan desa Gamtala pun dapat dihindari. Oleh sebab itulah transparansi dan akuntabilitas praktik pengelolaan keuangan pada desa Gamtala merupakan salah satu poin yang menarik untuk dapat dikaji lebih mendalam karena hal tersebut menjadi hakikat utama bagi entitas publik untuk dapat bertahan dan memaksimalkan perannya, apalagi bagi entitas publik yang berada pada lingkup sosial budaya yang berbeda dengan entitas publik lainnya.

Desa Gamtala yang dipilih dalam penelitian ini yaitu sebuah desa yang terletak di kecamatan Jailolo, kabupaten Halmahera Barat, provinsi Maluku Utara. Maluku utara merupakan daerah kepulauan yang terletak pada lintasan garis khatulistiwa. Berada pada $124^{0}-129^{0}$ bujur timur dan $3^{0}$ - $3^{0}$ lintang selatan. Pulau terbesarnya dan paling utama adalah Halmahera, Obi, Sula, Morotai, Bacan, Ternate, Makian dan Tidore. Maluku utara sendiri di sebelah utara berbatasan dengan Samudra Pasifik, sebelah selatan berbatasan dengan Laut Seram, sebelah timur berbatasan dengan Laut Halmahera dan di sebelah barat berbatasan dengan Laut Maluku. Fisiografi Maluku Utara dibentuk oleh relief-relief besar, dimana palung-palung oseanis dan punggung-punggung pegunungan saling berganti secara amat mencolok.

Kabupaten Halmahera Barat dengan Ibukota Jailolo adalah salah satu kabupaten yang berada di provinsi Maluku Utara. Kabupaten ini dihuni oleh beraneka ragam suku/etnis baik suku asli maupun suku pendatang, dengan suku aslinya adalah suku Tala'i, suku Ternate, suku Wayoli, suku Gorap, suku Loloda, dan suku Gamkonora. Dengan adanya beragam suku yang ada beragam pula adat istiadat, bahasa dan tradisi yang ada di kabupaten ini. Kabupaten Halmahera memiliki potensi sumber alam yang melimpah. Sebagai salah satu daerah tujuan wisata yang memiliki keragaman objek wisata dan daya tarik yang menjadi aset daerah sehingga perlu untuk dikembangkan secara maksimal guna mensejahterahkan masyarakat sekitar objek wisatanya. Desa Gamtala sebagai salah satu daerah tujuan wisata. Secara administratif, desa Gamtala termasuk dalam wilayah Kecamatan Jailolo, Kabupaten Halmahera Barat. Desa gamtala sebagai destinasi desa wisata dengan beragam potensi yang dimiliki, seperti pemandian air panas, hutan mangrove, adat istiadat dan hutan rempahrempah yang dimilikinya serta keramah-tamahan masyarakat adat - Suku Sahu - dalam menerima tamu yang merupakan nilai tersendiri yang menjadikan desa ini memiliki daya tarik bagi para wisatawan yang datang berkunjung. Namun, belum dimaksimalkan atau diberdayakan secara optimal oleh penduduk setempat karena beragam kendala. 
Sebagian besar penduduk desa Gamtala bermata pencaharian dibidang pertanian, hal ini didukung dengan potensi ketersediaan lahan untuk bercocok tanam dengan tingkat kesuburan tanah yang alami, dan komoditi unggulan yang dimiliki desa ini berupa rempah-rempah. Sebagai destinasi desa wisata, maka pembangunkan desa ini menjadi penting sehingga praktik pengelolaan keuangan di desa Gamtala menarik untuk dicermati.

Berkaitan dengan hal tersebut, adapun beberapa permasalahan penelitian yang akan dijawab dalam penelitian ini, antara lain:

1. Siapa saja pihak-pihak yang terlibat dalam proses pengelolaan keuangan di desa Gamtala?

2. Bagaimana proses pengelolaan keuangan di desa Gamtala?

3. Bagaimana pihak-pihak yang terlibat memahami dan memaknai akuntabilitas dalam pengelolaan keuangan di desa Gamtala?

\section{TINJAUAN PUSTAKA DAN PERUMUSAN HIPOTESIS}

\section{Konsep Pembangunan Desa}

Pembangunan adalah pengharapan akan kemajuan dalam sosial serta ekonomi dan untuk setiap negara mempunyai pandangan maupun nilai-nilai yang berlainan mengenai apa yang dimaksud dengan di "harapkan" itu (Roslinda, Okta, 2014), dimana pembangunan masyarakat desa (pedesaan) adalah seluruh kegiatan pembangunan yang berlangsung di desa dan meliputi seluruh aspek kehidupan masyarakat, serta dilaksanakan secara terpadu dengan mengembangkan swadaya gotong royong. Menurut Undang-Undang No 6 Tahun 2014 tentang desa pasal 78 ayat 1 menayatakan bahwa pembangunan desa bertujuan meningkatkan kesejahteraan masyarakat desa dan kualitas hidup manusia serta penanggulangan kemiskinan melalui pemenuhan kebutuhan dasar, pembangunan sarana dan prasarana desa, pengembangan potensi ekonomi lokal, serta pemanfaatan sumber daya alam dan lingkungan secara berkelanjutan. Pembangunan desa meliputi;

\section{Tahap perencanaan,}

Pemerintah desa menyusun perencanaan pembangunan desa sesuai dengan kewenangannya dengan mengacu pada perencanaan pembangunan kabupaten/kota. Perencanaan pembangunan desa sebagaimana dimaksud pada ayat (1) disusun secara berjangka meliputi:

a. Rencana Pembangunan Jangka Menengah Desa untuk jangka waktu 6 (enam) tahun; dan

b. Rencana Pembangunan Tahunan Desa atau yang disebut Rencana Kerja Pemerintah Desa, merupakan penjabaran dari Rencana Pembangunan Jangka Menengah Desa untuk jangka waktu 1 (satu) tahun melalui musyawarah yang mengikutsertakan masyarakat desa dengan perhatikan kebutuhan masyarakat desa sebagai berikut: 
Akuntabilitas Praktik Pengelolaan Keuangan Desa..

- Peningkatan kualitas dan akses terhadap pelayanan dasar;

- Pembangunan dan pemeliharaan infrastruktur dan lingkungan berdasarkan kemampuan teknis dan sumber daya lokal yang tersedia;

- Pengembangan ekonomi pertanian berskala produktif;

- Pengembangan dan pemanfaatan teknologi tepat guna untuk kemajuan ekonomi; dan

- Peningkatan kualitas ketertiban dan ketenteraman masyarakat desa berdasarkan kebutuhan masyarakat desa.

\section{Tahap pelaksanaan}

Pada tahap pelaksanaan pembangunan desa menurut Undang-Undang No 6 tahun 2014 Pasal 81 ayat 1-5 tentang desa bahwa pelaksanaan pembangunan desa dilaksanakan sesuai dengan rencana kerja pemerintah desa yang dilaksanakan oleh pemerintah desa dengan melibatkan seluruh masyarakat desa dengan semangat gotong royong, dimana pelaksanaan pembangunan desa dilakukan dengan memanfaatkan kearifan lokal dan sumber daya alam desa yang dilaksanakan sendiri oleh desa dengan program sektoral yang masuk ke desa diinformasikan kepada pemerintah desa untuk diintegrasikan dengan pembangunan desa.

\section{Tahap pengawasan}

Pada tahap pengawasan pembangunan desa menurut Undang-Undang No 6 tahun 2014 Pasal 82 ayat 1-6 tentang desa bahwa;

a. Masyarakat desa berhak mendapatkan informasi mengenai rencana dan pelaksanaan pembanguna desa.

b. Masyarakat desa berhak melakukan pemantauan terhadap pelaksanaan pembangunan desa.

c. Masyarakat desa melaporkan hasil pemantauan dan berbagai keluhan terhadap pelaksanaan pembangunan desa kepada pemerintah desa dan badan permusyawaratan desa.

d. Pemerintah desa wajib menginformasikan perencanaan dan pelaksanaan rencana pembangunan jangka menengah desa, rencana kerja pemerintah desa, dan Anggaran Pendapatan dan Belanja Desa kepada masyarakat desa melalui layanan informasi kepada umum dan melaporkannya dalam musyawarah desa paling sedikit 1 (satu) tahun sekali.

e. Masyarakat desa berpartisipasi dalam musyawarah desa untuk menanggapi laporan pelaksanaan pembangunan desa.

\section{Konsep Alokasi Dana Desa (ADD)}

Menurut Undang-undang No 60 tahun 2014 pasal 1 ayat 2 bahwa dana desa adalah dana yang bersumber dari Anggaran pendapatan Belanja Negara yang diperuntungkan bagi desa yang ditransfer melalui Anggaran Pendapatan Belanja Daerah kabupaten/kota dan digunakan untuk membiayai 
penyelenggaraan pemerintahan, pelaksanaan pembangunan, pembinaan pemasyarakatan, dan pemberdayaan masyarakat. Sedangkan menurut Thomas (2013) Alokasi Dana Desa selanjutnya disebut ADD adalah dana yang bersumber dari APBD yang dialokasikan dengan tujuan pemerataan kemampuan keuangan antar desa untuk mendanai kebutuhan desa dalam rangka penyelenggaraan pemerintahan dan pelaksanaan pembangunan serta pelayanan masyarakat. Alokasi Dana Desa (ADD) merupakan perolehan bagian keuangan desa dari Kabupaten yang penyalurannya melalui Kas Desa.

Menurut PP No 43 Tahun 2014 pasal 96 ayat 2 menyatakan bahwa ADD yang dialokasikan Pemerintah daerah kabupaten/kota dalam anggaran pendapatan dan belanja daerah kabupaten/kota ADD setiap tahun anggaran paling sedikit 10\% (sepuluh perseratus) dari dana perimbangan yang diterima kabupaten/kota dalam anggaran pendapatan dan belanja daerah setelah dikurangi dana alokasi khusus, yang mana pengalokasian ADD mempertimbangkan:

a. Kebutuhan penghasilan tetap kepala Desa dan perangkat Desa; dan

b. Jumlah penduduk Desa, angka kemiskinan Desa, luas wilayah Desa, dan tingkat kesulitan geografis Desa.

Pelaksanaan Alokasi Dana Desa (ADD) didasarkan atas prinsip-prisip :

1) Seluruh kegiatan dilaksanakan secara transparan / terbuka dan diketahui oleh masyarakat luas.

2) Masyarakat berperan aktif mulai proses perencanaan, pelaksanaan, pengawasan dan pemeliharaan.

3) Seluruh kegiatan dapat dipertanggungjawabkan secara administratif, teknis dan hukum.

4) Memfungsikan peran lembaga kemasyarakatan sesuai tugas pokok dan fungsinya.

5) Hasil kegiatan dapat diukur dan dapat dinilai tingkat keberhasilannya.

6) Hasil kegiatan dapat dilestarikan dan dikembangkan secara berkelanjutan dengan upaya pemeliharaan melalui partisipasi masyarakat

\section{Pengelolaan Keuangan Desa}

Menurut PP No 43 tahun 2014 pasal 90 menyatakan bahwa Kepala Desa adalah pemegang kekuasaan pengelolaan keuangan Desa dilaksanakan dalam masa 1 (satu) tahun anggaran terhitung mulai tanggal 1 Januari sampai dengan 31 Desember, dimana Pengelolaan keuangan Desa meliputi:
a. perencanaan;
b. pelaksanaan;
c. penatausahaan;
d. pelaporan; dan
e. pertanggungjawaban 
Akuntabilitas Praktik Pengelolaan Keuangan Desa..

Menurut PERMENDAGRI No 37 tahun 2007 pasal 3 tentang pedoman kekuasaan pengelolaan keuangan desa dinyatakan bahwa yang berwewenang untuk melakukan pengelolaan keuangan desa adalah Kepala Desa sebagai kepala pemerintah desa yang memegang kekuasaan pengelolaan keuangan desa dan mewakili pemerintah desa dalam kepemilikan kekayaan desa yang mempunyai kewenangan untuk:

a. menetapkan kebijakan tentang pelaksanaan APBDesa

b. menetapkan kebijakan tentang pengelolaan barang desa

c. menetapkan bendahara desa

d. menetapkan petugas yang melakukan pemungutan penerimaan desa; dan

e. menetapkan petugas yang melakukan pengelolaan barang milik desa.

Kepala desa dalam melaksanakan tugas dan kewenangannya dibantu oleh Pelaksana Teknis Pengelolaan Keuangan Desa (PTPKD) yang merupakan perangkat desa, terdiri dari:

1. Sekretaris Desa; yang betindak selaku koordinator pelaksanaan pengelolaan keuangan desa dan bertanggung jawab kepada kepala desa mempunyai tugas:

a. Menyusun dan melaksanakan kebijakan pengelolaan APBDesa.

b. Menyusun dan melaksanaan kebijakan pengelolaan barang desa.

c. Menyusun raperdes apbdesa, perubahan apbdesa dan pertanggung jawaban Pelaksanaan APBDesa.

d. Menyusun rancangan keputusan kepala desa tentang pelaksanaan peraturan desa tentang APBDesa dan perubahan APBDesa.

2. Perangkat desa lainnya, yaitu: Unsur Pelaksana Lapangan (KAUR): pelaksana teknis Pengelolaan keuangan desa dan Bendahara desa: (a) bendahara umum desa; (b) bendahara penerimaan; (c) bendahara pengeluaran; (d) bendahara barang.

\section{Struktur APBDesa}

Menurut PERMENDAGRI No 37 tahun 2007 pasal 4 tentang pedoman pengelolaan keuangan desa bahwa struktur Anggaran pendapatan belanja Desa (APBDesa) terdiri dari:

\section{Pendapatan Desa;}

Pendapatan desa meliputi semua penerimaan uang melalui rekening desa yang merupakan hak desa dalam 1 (satu) tahun anggaran yang tidak perlu dibayar kembali oleh desa. Pendapatan Desa terdiri dari:

a. Pendapatan Asli Desa (PADesa);

b. Bagi Hasil Pajak Kabupaten/Kota; 
c. Bagian dari Retribusi Kabupaten/Kota;

d. Alokasi Dana Desa (ADD);

e. Bantuan Keuangan dari Pemerintah, Pemerintah Provinsi, Peerintah Kabupaten/Kota dan Desa lainnya;

f. Hibah;

g. Sumbangan Pihak Ketiga.

\section{Belanja Desa}

Menurut PP No 43 Tahun 2014 ayat 100 menyatakan bahwa Belanja Desa yang ditetapkan dalam APB Desa digunakan dengan ketentuan:

a. paling sedikit 70\% (tujuh puluh perseratus) dari jumlah anggaran belanja Desa digunakan untuk mendanai penyelenggaraan Pemerintahan Desa, pelaksanaan pembangunan Desa, pembinaan kemasyarakatan Desa, dan pemberdayaan masyarakat Desa; dan

b. paling banyak 30\% (tiga puluh perseratus) dari jumlah anggaran belanja Desa digunakan untuk:

1. Penghasilan tetap dan tunjangan kepala Desa dan perangkat Desa;

2. Operasional Pemerintah Desa;

3. Tunjangan dan operasional Badan Permusyawaratan Desa; dan

4. Insentif rukun tetangga dan rukun warga

Belanja desa meliputi semua pengeluaran dari rekening desa yang merupakan kewajiban desa dalam 1 (satu) tahun anggaran yang tidak akan diperoleh pembayarannya kembali oleh desa. Belanja Desa terdiri dari:

a. Belanja langsung;
a. Belanja Pegawai;
b. Belanja Barang dan Jasa
c. Belanja Modal;

b. Belanja tidak langsung
a. Belanja Pegawai/Penghasilan Tetap;
b. Belanja Subsidi;
c. Belanja Hibah (Pembatasan Hibah);
d. Belanja Bantuan Sosial;
e. Belanja Bantuan Keuangan;
f. Belanja Tak Terduga; 
Akuntabilitas Praktik Pengelolaan Keuangan Desa..

\section{Pembiayaan Desa.}

Pembiayaan desa meliputi semua penerimaan yang perlu dibayar kembali dan/atau pengeluaran yang akan diterima kembali, baik pada tahun anggaran yang bersangkutan maupun pada tahuntahun anggaran berikutnya. Pembiayaan desa terdiri dari:

a. Penerimaan Pembiayaan, meliputi:

a. Sisa lebih perhitungan anggaran (SilPA) tahun sebelumnya.

b. Pencairan dana cadangan.

c. Hasil penjualan kekayaan desa yang dipisahkan.

d. Penerimaan pinjaman

b. Pengeluaran pembiayaan, meliputi:

a. Pembentukan dana cadangan.

b. Penyertaan modal desa.

c. Pembayaran utang

\section{Pertanggungjawaban dan Pelaporan Desa}

Menurut PERMENDAGRI No 37 tahun 2007 pasal 3 tentang pedoman kekuasaan pengelolaan keuangan desa bahwa Pertanggungjawaban ADD terintegrasi dengan pertanggungjawaban APBDesa, sehingga bentuk pertanggungjawabannya adalah pertanggung-jawaban APB Desa, dimana bentuk pelaporan atas Kegiatan-kegiatan dalam APB Desa yang dibiayai dari ADD.

Menurut PP No 43 Tahun 2014 ayat 103 menyatakan bahwa Kepala Desa menyampaikan laporan realisasi pelaksanaan APB Desa kepada bupati/walikota setiap semester tahun berjalan, yang mana Laporan semester pertama disampaikan paling lambat pada akhir bulan Juli tahun berjalan dan untuk semester kedua disampaikan paling lambat pada akhir bulan Januari tahun berikutnya. Selain itu pada Pasal 104 dinyatakan bahwa selain penyampaian laporan realisasi pelaksanaan APB Desa, kepala Desa juga menyampaikan laporan pertanggungjawaban realisasi pelaksanaan APB Desa kepada bupati/walikota setiap akhir tahun anggaran, yang merupakan bagian yang tidak terpisahkan dari laporan penyelenggaraan Pemerintahan Desa kepada bupati/walikota melalui camat yang sesuai dengan tugas, kewenangan, hak dan kewajiban kepala desa

\section{METODOLOGI PENELITIAN}

Penelitian ini dilakukan dengan menggunakan metode penelitian kualitatif. Paradigma yang digunakan dalam penelitian ini adalah paradigma interpretif. Penelitian ini dilaksanakan di desa Gamtala, Kecamatan Jailolo Kabupaten Halmahera Barat dengan harapan bahwa pemerintah desa 
mampu mengelola keuangan dengan baik. Sedangkan waktu yang digunakan dalam penelitian ini adalah selama 2 (bulan) bulan. Informan dalam penelitian ini ditunjuk secara purposive. Penunjukan ini ditentukan berdasarkan pertimbangan bahwa sejauh mana mereka memahami masalah yang dikaji sebagaimana yang dirumuskan dalam masalah penelitian

Dalam penelitian ini, data dikumpulkan dari sumber primer yaitu data yang didapatkan langsung dari informan dilapangan, serta sumber sekunder yaitu data yang diperoleh dari dokumendokumen, tulisan/artikel. Pengumpulan data dalam penelitian ini dilakukan melalui teknik In-depth interview, Observasi dan Studi Dokumentasi. Teknik analisis yang digunakan dalam penelitian ini sejalan dengan teknik analisis interaktif yang dikemukakan oleh Miles dan Huberman (1992) dalam Moleong (2005), yaitu: 1) Reduksi data (data reduction), 2) Penyajian Data (data display), dan 3) Menarik Kesimpulan (verifikasi).

\section{HASIL DAN PEMBAHASAN}

\section{Struktur Organisasi Pemerintahan Desa Gamtala}

Stuktur organisasi Desa Gamtala dilukiskan layaknya seorang manusia yang lengkap dengan kepala dan anggota tubuh seperti tangan dan kakinya. Setiap bagian ataupun posisi yang menduduki struktur organisasi tersebut saling berhubungan dan memiliki tugas masing-masing. Berdasarkan hasil wawancara dan observasi yang telah peneliti lakukan, secara struktur pemerintahan Desa Gamtala terdiri atas Kepala Desa, Badan Permusyawaratan Desa (BPD), Lembaga Adat, Sekretaris Desa, Kepala Urusan Administrasi, Kepala urusan Keuangan (Bendahara), Kepala Urusan Umum, Kepala Seksi Pemerintahan, Kepala Seksi Pembangunan, Kepala Seksi Kesejahteraan dan Ketua-Ketua RT (terlampir).

Kepala Desa memiliki tugas untuk mengurus dan mengatur pengelolaan harta kekayaan Desa Gamtala. Lembaga Adat adalah orang- orang yang memiliki peran dalam hal keagamaan, seperti halnya mengurus kelengkapan dan perlengkapan yang berkaitan dengan upacara-upacara di Desa Gamtala. Sekretaris Desa memiliki tugas dan tanggung jawab dibidang administrasi Desa Gamtala. Bendahara Desa memiliki tanggung jawab dalam mencatat dan mempertanggungjawabkan keluar masuknya kas, tabungan, deposito, pinjaman serta transaksi-transaksi keuangan lainnya yang berkaitan dengan kas Desa Gamtala. 
Akuntabilitas Praktik Pengelolaan Keuangan Desa..

\section{Luas Wilayah, Penduduk dan Batas Desa}

Desa Gamtala sering juga disebut desa wisata dengan luas wilayah 9.000 Ha. Ruben Kalengit, Kepala Desa Gamtala yang diwawancarai, menjelaskan batas desa Geamtala sebagai berikut :

a. Sebelah Utara berbatasan dengan hutan mangrove

b. Sebelah Selatan berbatasan dengan Gunung Tugu Aer

c. Sebelah Timur berbatasan dengan Desa Lolori, dan

d. Sebelah barat berbatasan dengan Desa Marimabati.

Lebih lanjut, kepala desa menjelaskan bahwa mengapa desa Gamtala disebut desa wisata dikarenakan desa Gamtala memiliki keindahan hutan mangrove, aliran sungai yang deras dan jernih serta terdapatnya mata air panas. Jumlah kepala keluarga yang menetap di desa Gamtala, lanjut kepala desa berjumlah sebanyak 170 kepala keluarga dengan mayoritas pencaharian penduduk bercocok tanam.

\section{Keunikan Desa Gamtala}

Ruben Kalengit, kepala Desa Gamtala yang menjabat sebagai kepala desa sejak tanggal 5 Juni 2006 menjelaskan bahwa alasannya menjadi kepala desa karena merasa terpanggil untuk melayani masyarakat. Apalagi di desa Gamtala yang unik dan indah. Keunikan desa Gamtala menurut beliau adalah dari wisata alam, banyaknya rempah-rempah dan luasnya hutan mangrove yang masih dilestarikan hingga saat ini.

\section{Prestasi, Tantangan dan Hambatan dalam pembangunan Desa Gamtala}

Menurut kepala desa, sejak beliau menjabat, beberpa prestasi telah dicapai. Hal ini terlihat dari pernyataan yang disampaikan oleh Kepala Desa Gamtala berikut ini:

“..... Beberapa prestasi yang torang so capai antara lain : Desa Gamtala sudah mendapatkan Piagam Sebagai Desa Bebas Buang Air Besar Sembarangan. Selain itu Desa Gamtala menjadi desa tempat pengolahan air bersih program pansimas".

Dari pernyataan di atas, terlihat bahwa masyarakat desa Gamtala memandang penting untuk membangun MCK (mandi cuci kakus) di rumahnya masing-masing, sehingga tidak ada lagi warga yang membuang kotoran sembarangan. Selain itu, pengolahan air bersih memungkinkan masyarakat desa lebih dapat hidup dengan sehat.

Ketika disinggung terkait hambatan dan tantangan menjadi kepala desa, Ruben Kalingit memberikan pernyataan : 
“... Disini (di Desa Gamtala) masih sering terjadi konflik antar pemuda, apalagi kalo ada acara (pesta) deng dorang (mereka) su baminum (minum-minuman keras), itu biasa kaco (terjadi perkelahian). Selain itu, pembangunan desa sering terhambat karena masih ada warga yang belum siap menerima program desa".

Dari pernyataan di atas, bisa dijelaskan bahwa masih sering terjadi konflik antar pemuda di desa Gamtala utamanya saat diadakannya pesta atau hiburan rakyat. Hal ini tentunya memerlukan perhatian dari pihak pemerintah desa dan dicarikan solusi yang tepat sehingga hal ini bisa di minimalisir atau dihilangkan.

Peran aktif masyarakat dalam pembangunan dibangkitkan lewat organisasi sistem yang ada di lingkungannya. Salah satu faktor yang cukup mempengaruhi peran serta masyarakat adalah pandangan hidup. Secara umum pandangan hidup ini dapat diklasifikasikan atas 3 kelompok yaitu masyarakat yang berpandangan terbuka atau yang mudah menerima perubahan, berpandangan tertutup atau yang seringkali menolak perubahan, dan berpandangan terbatas. Masyarakat yang berpandangan terbatas biasanya bisa menerima perubahan tetapi tidak semua, umumnya kelompok ini jauh lebih maju dari dua kelompok masyarakat sebelumnya. Di samping itu peran dunia usaha dalam pembangunan perdesaan juga sangat dibutuhkan sehingga terjadi sinergi yang optimal antara pemerintah, masyarakat dan dunia usaha. Sedangkan peran pemerintah dalam pembangunan perdesaan adalah untuk mendukung terwujudnya situasi kondisi wilayah yang kundusif dan memfasilitasi seluruh program pembangunan yang sasarannya adalah masyarakat desa. Dengan demikian diharapkan dapat mendukung kelancaran pelaksanaan implementasi Alokasi Dana Desa di Desa Gamtala.

\section{Pengelolaan Dana Desa Gamtala}

Menurut PP No 43 tahun 2014 pasal 90 menyatakan bahwa Kepala Desa adalah pemegang kekuasaan pengelolaan keuangan Desa dilaksanakan dalam masa 1 (satu) tahun anggaran terhitung mulai tanggal 1 Januari sampai dengan 31 Desember, dimana Pengelolaan keuangan Desa meliputi:
a. perencanaan;
b. pelaksanaan;
c. penatausahaan;
d. pelaporan; dan
e. pertanggungjawaban

Saat dikonfirmasi terkait dana desa di desa Gamtala, kepala desa menjelaskan : 
Akuntabilitas Praktik Pengelolaan Keuangan Desa..

“.... Pada prinsipnya, pengelolaan dana desa memprioritaskan kebutuhan masyarakat dengan mempertimbangkan tiga hal yaitu pembangunan fisik, pembinaan dan pemberdayaan".

Pembangunan fisik yang dimaksud oleh kepala desa di atas yaitu pembangunan sarana dan prasarana seperti pembangunan jalan setapak desa dan pembangunan posyandu desa. Adapun pembinaan terkait dengan pembinaan organisasi-organisasi di desa seperti PKK dan karang taruna. Sedangkan pemberdayaan masayarakat ini dikhususkan untuk pemberdayaan individu untuk meningkatkan kesejahteraan masyarakat.

\section{Pihak-pihak yang terlibat dalam proses pengelolaan keuangan di desa Gamtala}

Pernyataan Kepala Desa Gamtala ketika dimintai keterangan terkait siapa saja yang terlibat dalam proses pengelolaan keuangan di desa Gamtala, beliau menyatakan:

“... Ada empat pihak yang terlibat dalam proses pengelolaan keuangan Desa yaitu Tim Teknis Pelaksana Keuangan Desa (TPKD), Tim Pengelola Kegiatan, Kepala Desa dan Bendahara Desa".

Melihat pernyataan kepala desa tersebut di atas hal ini sudah sesuai dengan PERMENDAGRI No 37 tahun 2007 pasal 3 tentang pedoman kekuasaan pengelolaan keuangan desa yang menyatakan bahwa Kepala desa dalam melaksanakan tugas dan kewenangannya dibantu oleh Pelaksana Teknis Pengelolaan Keuangan Desa (PTPKD) yang merupakan perangkat desa, terdiri dari:

1. Sekretaris Desa, yang betindak selaku koordinator pelaksanaan pengelolaan keuangan desa dan bertanggung jawab kepada kepala desa mempunyai tugas:

e. Menyusun dan melaksanakan kebijakan pengelolaan apbdesa.

f. Menyusun dan melaksanaan kebijakan pengelolaan barang desa.

g. Menyusun raperdes apbdesa, perubahan apbdesa dan pertanggung jawaban Pelaksanaan APBDesa.

h. Menyusun rancangan keputusan kepala desa tentang pelaksanaan peraturan desa tentang APBDesa dan perubahan APBDesa.

2. Perangkat desa lainnya, yaitu Unsur Pelaksana Lapangan (KAUR): pelaksana teknis Pengelolaan keuangan desa dan Bendahara desa: (a) bendahara umum desa; (b) bendahara Penerimaan; (c) bendahara pengeluaran; (d) bendahara barang.

\section{Proses pengelolaan keuangan di desa Gamtala}

PERMENDAGRI No 37 tahun 2007 pasal 3 tentang pedoman kekuasaan pengelolaan keuangan desa dinyatakan bahwa yang berwewenang untuk melakukan pengelolaan keuangan desa adalah Kepala Desa sebagai kepala pemerintah desa yang memegang kekuasaan pengelolaan keuangan desa 
dan mewakili pemerintah desa dalam kepemilikan kekayaan desa yang mempunyai kewenangan untuk:

a. menetapkan kebijakan tentang pelaksanaan APBDesa

b. menetapkan kebijakan tentang pengelolaan barang desa

c. menetapkan bendahara desa

d. menetapkan petugas yang melakukan pemungutan penerimaan desa; dan

e. menetapkan petugas yang melakukan pengelolaan barang milik desa.

Saat dikonfirmasi, kepala Desa Gamtala menyatakan :

“... Proses pengelolaan keuangan di desa Gamtala mengacu pada program yang diusulkan oleh masyarakat desa dengan mempertimbangkan anggaran dana desa yang ada”.

Keuangan desa adalah semua hak dan kewajiban desa dalam rangka penyelenggaraan pemerintahan desa yang dapat dinilai dengan uang, termasuk didalamnya segala bentuk kekayaan yang berhubungan dengan hak dan kewajiban desa tersebut. Pengelolaan keuangan desa adalah keseluruhan proses kegiatan, yang meliputi perencanaan dan penganggaran, pelaksanaan dan penatausahaan, pelaporan dan pertanggungjawaban, serta pengawasan keuangan desa. Pengelolaan keuangan desa dilakukan secara tertib dan terencana yang ditetapkan di dalam Anggaran Pendapatan dan Belanja Desa (APBDesa). Keuangan desa dikelola dalam masa 1 (satu) tahun anggaran yakni mulai tanggal 1 Januari sampai dengan tanggal 31 Desember.

Kepala desa sebagai kepala pemerintah desa adalah pemegang kekuasaan pengelolaan keuangan desa dan mewakili pemerintah desa dalam kepemilikan kekayaan desa yang dipisahkan. Kepala desa mempunyai kewenangan:

1. Menetapkan kebijakan tentang pelaksanaan APBDesa;

2. Menetapkan kebijakan tentang pengelolaan barang desa;

3. Menetapkan bendahara desadengan Keputusan Kepala Desa;

4. Menetapkan petugas yang melakukan pemungutan penerimaan desa; dan

5. Menetapkan petugas yang melakukan pengelolaan barang milik desa.

Kepala Desa dalam melaksanakan pengelolaan keuangan desa, dibantu oleh Pelaksana Teknis Pengelolaan Keuangan Desa (PTPKD). Pelaksana Teknis Pengelolaan Keuangan Desa (PTPKD) adalah Perangkat Desa, terdiri dari : 1) Sekretaris Desa; dan 2) Perangkat Desa lainnya. Kepala Desa menetapkan Bendahara Desa dengan Keputusan Kepala Desa. Sekretaris Desa bertindak selaku koordinator pelaksanaan pengelolaan keuangan desa dan bertanggung jawab kepada Kepala Desa. Sekretaris Desa mempunyai tugas : 
Akuntabilitas Praktik Pengelolaan Keuangan Desa..

1. Menyusun dan melaksanakan Kebijakan Pengelolaan APBDesa.

2. Menyusun dan melaksanaan Kebijakan Pengelolaan Barang Desa.

3. Menyusun Rancangan Peraturan Desa Tentang APBDesa, perubahan APBDesa dan pertanggungjawaban pelaksanaan APBDesa.

4. Menyusun Rancangan Keputusan Kepala Desa tentang Pelaksanaan Peraturan Desa tentang APBDesa dan Perubahan APBDesa.

\section{Pihak-pihak yang terlibat memahami dan memaknai akuntabilitas dalam pengelolaan keuangan di desa Gamtala}

Akuntabilitas sistem pengelolaan ADD dimaksudkan sebagai upaya untuk mewujudkan tata kelola pemerintahan yang baik (good governance). Sebagaimana dikemukakan oleh Haryanto (2007: 10), bahwa prinsip atau kaidah-kaidah good governance adalah adanya partisipasi, transparansi dan kebertanggungjawaban dalam pelaksanaan pemerintahan dan pembangunan. Pengelolaan ADD sebagai bagian dari pelaksanaan pembangunan di desa, sudah seharusnya memegang teguh prinsipprinsip yang merupakan indikator good governance tersebut. Oleh karena itu dalam menggambarkan sistem akuntabilitas pengelolaan ADD, akan diuraikan lebih lanjut berdasarkan data dan informasi, sejauhmana indikator tersebut dijalankan di wilayah penelitian.

Tingkat akuntabilitas dalam implementasi pengelolaan ADD dimulai dari perencanaan, pelaksanaan, dan pertanggungjawaban dengan berpedoman pada prinsip-prinsip sebagai berikut:

a. Pengelolan keuangan ADD merupakan bagian yang tidak terpisahkan dari pengelolaan keuangan desa dalam APBDes.

b. Seluruh kegiatan yang didanai dari ADD direncanakan secara terbuka melalui musyawarah perencanaan pembangunan desa yang hasilnya dituangkan dalam Peraturan Desa tentang Anggaran Pendapatan dan Belanja Desa, serta dilaksanakan dan dievaluasi secara terbuka dengan melibatkan seluruh unsur masyarakat desa.

c. Seluruh kegiatan harus dapat dipertanggungjawabkan secara administrasi, teknis, maupun hukum.

d. Alokasi Dana Desa dilaksanakan dengan prinsip hemat, terarah, dan terkendali.

e. ADD tidak diperbolehkan untuk ganti rugi tanah, bangunan-bangunan yang tidak/kurang memiliki manfaat sosial ekonomi, serta pembangunan tempat ibadah baru. 
Dari ketentuan tersebut, khususnya pada butir b, sudah sangat jelas menyebutkan bahwa pengelolaan ADD harus dilaksanakan secara terbuka melalui musyawarah desa dan hasilnya dituangkan dalam Peraturan Desa (Perdes). Ketentuan tersebut menunjukkan komitmen dari stakeholder/pengambil keputusan bahwa pengelolaan ADD harus memenuhi kaidah good governance yang harus dilaksanaan oleh para pelaku dan masyarakat desa. Adanya komitmen yang kuat dari Pemerintah Desa Gamtala untuk mengembangkan tingkat partisipasi masyarakat, sesuai dengan informasi dari bendahara desa sebagai berikut:

"... Pemerintah Desa saat ini memang memberikan kesempatan kepada masyarakat untuk lebih banyak berperan aktif dalam pembangunan, mulai dari perencanaan, pelaksanaan, pengendalian dan evaluasi serta paska kegiatan. Hal itu dilakukan semata-mata hanya untuk melaksanakan konsep dasar tingkat partisipasi melalui pemberdayaan masyarakat. Khusus mengenai kebijakan perencanaan ADD sepenuhnya diserahkan kepada musyawarah masyarakat desa, pemerintah desa hanya memberikan pandangan arah penggunaan dana untuk menghindari penyelewengan penggunaan dan melakukan kesamaan program pembangunan daerah. Hal terpenting forum musrenbangdes tersebut juga sebagai media belajar masyarakat dalam mengelola pembangunan.."

Pendapat informan tersebut memberikan sinyal bahwa dalam menumbuhkan tingkat partisipasi masyarakat desa, khususnya dalam implementasi program ADD harus dilaksanakan secara bahu membahu semua stakeholders dan komprehensif menyelesaikan berbagai permasalahan di desa. Pelaksanaan tersebut dalam rangka penerapan prinsip partisipatif pembangunan masyarakat desa yang didukung oleh prinsip-prinsip transparan, akuntabel dan responsive. Dari sisi partisipasi sesuai dengan arti partisipasi (Tjokroamidjojo, 2000: 78) yaitu keterlibatan setiap warga negara dalam pengambilan keputusan baik secara langsung maupun melalui institusi yang mewakilinya. Dengan demikian akan didukung pula penerapan prinsip transparan, akuntabel dan responsif. Oleh karena itu untuk mengetahui secara lebih jelas, implementasi prinsip-prinsip tersebut perlu diketahui mulai dari perencanaan, mekanisme penentuan arah penggunaan dana, pelaksanaan dan sistem pertanggungjawaban dan pengawasan ADD secara lengkap.

APBDesa yang disusun harus dapat menyajikan informasi secara terbuka, jelas dan mudah diakses oleh masyarakat mengenai tujuan, sasaran, sumber pendanaan pada setiap jenis objek belanja serta hubungan antara besaran anggaran dengan manfaat dan hasil yang ingin dicapai dari suatu kegiatan yang dianggarkan. Anggota masyarakat memiliki hak dan akses yang sama untuk mengetahui proses anggaran karena menyangkut aspirasi dan kepentingan masyarakat, terutama pemenuhan kebutuhan masyarakat. APBDesa yang disusun harus mampu menunjukkan informasi yanglengkap untuk kepentingan pemerintah, pelaksanaan kegiatan, dan masyarakat. Penggunaan 
Akuntabilitas Praktik Pengelolaan Keuangan Desa..

anggaran harus dipertanggungjawabkan dan dikontrol melalui mekanisme pelaporan yangtelah ditetapkan. Masyarakat juga berhak untuk menuntut pertanggungjawaban atas rencana taupun pelaksanaan anggaran tersebut.

Transparansi dan pengetahuan masyarakat yang memadai tentang proses penyusunan dan penetapan pos-pos anggaran akan mendorong kinerja dan kontrol publik terhadap pelaksanaan pembangunan. Anggaran yang telah ditetapkan dan disetujui harus dilaksanakan melalui mekanisme dan prosedur yang jelas. Akuntabilitas perencanaan dan pelaksanaan anggaran merupakan keharusan sebagai wujud pertanggungjawaban pemerintah desa kepada masyarakat.

Laporan Keuangan yang telah dibuat dengan menggunakan sistem akuntansi sederhana diatas menunjukkan bahwa konsep akuntabilitas proses telah terpenuhi, walaupun belum sempurna. Akuntabilitas proses menekankan pada ketepatan penggunaan prosedur dalam melaksanakan tugas sehingga memiliki kecukupan sistem informasi akuntansi dan sistem informasi manajemen yang baik Ellwood dalam Mardiasmo (2002: 22).

Laporan pertanggung jawaban atas realisasi penggunaan dana desa dibuat dalam tiga tahap. Yaitu tahap pertama saat pencairan dan realisasi 40\%, tahap kedua juga 40\% dan tahap ketiga 20\%. Laporan realisasi tahap pertama dibuat untuk pencairan dana tahap ke dua. Demikian juga untuk tahap ketiga. Pertanggungjawaban dan transparansi dana dilakukan dengan melibatkan tim baik dalam perencanaan, penggunaan dana dan pembuatan laporan. Sebagaimana yang dikemukakan oleh kepala desa Gamtala, bapak Ruben Kalingit:

“... Pertanggungjawaban itu penting dalam rangka keterbukaan kepada masyarakat, artinya kepercayaan. Kalau kita tidak pernah mempertanggungjawabkan, mana buktinya? Kan begitu. Tapi dengan adanya pertanggungjawaban tersebut, maka pemimpin akan dipercaya. Kita melibatkan semua tim dalam pengelolaan dana dan pembuatan laporan".

Kredibilitas dan wibawa individu maupun entitas Desa Gamtala menjadi pertimbangan utama mengapa akuntansi melalui pelaporan keuangan yang dibuat oleh pengurus Desa Gamtala menjadi poin penting dalam pengelolaan keuangan Desa Gamtala. Kecurigaan dan ketidakpercayaan muncul dari masyarakat Desa Gamtala dan masyarakat sekitar, apabila pengurus Desa Gamtala tidak dapat mepertanggungjawabkan secara transparan terkait pengelolaan keuangan Desa Gamtala, terutama dana-dana yang berasal dari masyarakat maupun instansi pemerintah yang memberikan sumbangan. 
Adanya laporan keuangan yang dibuat juga sebagai bukti untuk memperkuat opini pengelola keuangan dalam rangka menghapus kecurigaan-kecurigaan yang berdampak pada turunya kredibilitas masyarakat. Alasan yang memeperkuat adanya pelaporan dan pencataatan setiap transaksi yang terjadi mengasumsikan bahwa peran akuntansi sebagai instrumen transparansi dan akuntabilitas pengelolaan keuangan tidak diabaikan. Fakta ini menggambarkan bahwa masyarakat, khususnya pengurus Desa Gamtala telah memahami dan menjunjung tinggi serta menerapkan dengan baik prinsip-prinsip akuntabilitas dan transparansi dengan penggunaan sistem akuntansi pada pengelolaan keuangan Desa Gamtala. Selain sebagai instrumen transparansi dan akuntabilitas publik, fungsi akuntansi juga terlihat untuk mendorong praktik-praktik yang bersih. Praktik yang bersih merupakan syarat terpenuhinya akuntabilitas kejujuran dan akuntabilitas hukum dalam dimensi akuntabilitas publik yang disampaikan oleh Ellwood dalam Mardiasmo (2002: 22).

\section{SIMPULAN DAN SARAN}

\section{Kesimpulan}

Akuntabilitas Praktik Pengelolaan Dana Desa di Desa Gamtala Kabupaten Halmahera Barat, dapat diambil beberapa kesimpulan sebagai berikut.

1. Perencanaan program ADD (Alokasi Dana Desa) di Desa Gamtala secara bertahap telah melaksanakan konsep pembangunan partisipatif masyarakat desa yang dibuktikan dengan penerapan prinsip partisipatif, responsif, transparansi. guna pembelajaran sumber daya masyarakat desa dalam rangka mewujudkan pemberdayaan masyarakat desa melalui forum Musrenbangdes (Musyawarah Perencanaan Pembangunan Desa).

2. Pelaksanaan program ADD (Alokasi Dana Desa) di Desa Gamtala telah menerapkan prinsipprinsip partisipatif, responsif, transparan. Penerapan prinsip akuntabilitas pada tahap ini dalam bentuk pertanggungjawaban fisik dan administrasi dengan membuat laporan pertanggungjawaban dalam tiga tahap beserta bukti-bukti transaksinya.

3. Pertanggungjawaban ADD baik secara teknis maupun administrasi sudah baik, namun dalam hal pertanggungjawaban administrasi keuangan kompetensi sumber daya manusia pengelola merupakan kendala utama sehingga masih memerlukan pendampingan dari aparat Pemerintah Daerah guna penyesuaian perubahan aturan setiap tahun.

4. Program Alokasi Dana Desa merupakan konsep ideal Pemerintah Kabupaten Halmahera Barat dalam rangka melaksanakan Pembangunan partisipatif masyarakat desa, ternyata 
Akuntabilitas Praktik Pengelolaan Keuangan Desa..

mendapat respon/tanggapan positif masyarakat yang sangat diharapkan keberlanjutannya guna peningkatan pembangunan desa.

\section{Saran}

Dari beberapa penjelasan dan kesimpulan di atas, maka untuk pencapaian sasaran maksimal dalam pembangunan partisipatif masyarakat desa yang diimplementasikan melalui program Alokasi Dana Desa (ADD), maka harus ada pembenahan dalam beberapa hal sebagai berikut:

1. Untuk meningkatkan keberhasilan program Alokasi Dana Desa (ADD) di Desa Gamtala perlu dilakukan langkah-langkah sebagai berikut :

a. Pelatihan bagi Perangkat Desa selaku Tim Pelaksana Desa tentang manajemen dan administrasi pengelolaan ADD.

b. Penyediaan sarana yang memadai bagi Tim Fasilitasi Kecamatan untuk menunjang kegiatan supervisi, pemantauan, evaluasi dan monitoring kegiatan ADD di desa.

c. Dilakukan monitoring dan evaluasi secara berkelanjutan untuk memperbaiki kinerja di semua sisi baik fisik, teknis, maupun administrasi (pertanggungjawaban/SPJ).

2. Pembinaan pengelola ADD merupakan sarana efektif untuk keberhasilan program ADD. Oleh karena itu pemahaman prinsip partisipatif, transparansi, dan akuntabilitas harus dilakukan seefektif kepada aparat pemerintah desa, BPD, lembaga kemasyarakatan desa, tokoh masyarakat dan tokoh agama guna meningkatkan semangat, motivasi, dan kreatifitas masyarakat dalam pembangunan desa.

3. Perlu dibangun kembali kepercayaan masyarakat terhadap pemerintah desa dengan jalan melaksanakan prinsip responsif terhadap kebutuhan/usulan masyarakat dan merealisasikannya dalam bentuk kegiatan pembangunan desa.

4. Dalam penelitian ini, peneliti mempunyai waktu yang terbatas untuk menggali informasi yang mendalam dengan para informan yang disebabkan karena tingginya tingkat kesibukan para informan. Sehingga, diharapkan untuk penelitian selanjutnya keterbatasan ini dapat diatasi dengan cara menambah rentang waktu penelitian yang lebih banyak.

\section{Daftar Pustaka}

Ambara, IG. Adi. 2011. Tesis: Peran Modal Sosial dalam Pemberdayaan Ekonomi Desa Gamtala/Pakraman (Studi Kasus LPD Desa Gamtala Tibubiyu, Kabupaten Tabanan Bali). Malang: Universitas Brawijaya. 
Atmadja, Anantawikrama Tungga. 2006. Penyertaan Modal Sosial dalam Struktur Pengendalian Interen pada Lembaga Perkreditan Desa (LPD): Studi Kasus pada Lima LPD di Kabupaten Buleleng, Propinsi Bali. Tesis Akuntansi yang tidak diterbitkan. Surabaya: Program Pasca Sarjana Universitas Airlangga.

LAN dan BPKP. 2000. Akuntabilitas dan Good Governance, Modul 1 dari 5 Modul Sosialisasi Sistem Akuntabilitas Kinerja Instansi Pemerintah. Jakarta: Penerbit LAN

Mardiasmo. 2002. Akuntansi Sektor Publik. Yogyakarta: Andi.

Moleong, Lexy. J. 2005. Metodologi Penelitian Kualitatif. Bandung: PT. Remaja Rosdakarya.

Peraturan Menteri Dalam Negeri Nomor 72 Tahun 2005 Tentang Desa

Peraturan Pemerintah. No. 43 Tahun 2014 tentang Peraturan Pelaksanaan Undang-Undang No.6 Tahun 2014 tentang Desa;

Peraturan Pemerintah.. No.60 Tahun 2014 tentang Dana Desa yg bersumber dari APBN

Peraturan Menteri Dalam Negeri No. 4 Tahun 2007 tentang Pedoman Pengelolaan Kekayaan Desa.

Peraturan Menteri Dalam Negeri No. 37 Tahun 2007 tentang Pedoman Pengelolaan Keuangan Desa;

Peraturan Menteri Dalam Negeri No. 113 Tahun 2014 tentang Pedoman Pengelolaan Keuangan Desa;

Roslinda, Okta. 2014. Pengelolaan Alokasi Dana Desa (Add) Dalam Menunjang Pembangunan Pedesaan (Studi Kasus : Desa Segodorejo dan Desa Ploso Kerep, Kecamatan Sumobito, Kabupaten Jombang). Jurnal Imiah, Fakultas Ekonomi Dan Bisnis Universitas Brawijaya. Malang

Simanjuntak, D.A dan Yeni, Januarsi.2011 Akuntabilitas dan Pengelolaan Kuangan di Masjid. Simposium Nasional Akuntansi XIV Aceh. Banten: Universitas Sultan Ageng Tirtayasa.

Thomas. 2013. Pengelolaan Alokasi Dana Desa Dalam Upaya Meningkatkan Pembangunan Di Desa Sebawang Kecamatan Sesayap Kabupaten Tana Tidung, eJournal Pemerintahan Integratif, Vol 1 pp 51-64.

Undang-Undang Nomor 6 Tahun 2014 Tentang Desa;

Widjaja, HAW. 2004. Otonomi Desa Merupakan Otonomi Yang Asli, Bulat, dan Utuh. Jakarta: PT. Raja Grafindo Persada 